\title{
Pelatihan Bahasa Arab Peribadatan bagi Masyarakat Dusun Klampok, Desa Giripurwo, Kecamatan Purwosari, Kabupaten Gunungkidul, Daerah Istimewa Yogyakarta
}

\section{Imam Wicaksono}

Program Studi Sastra Arab, Departemen Bahasa dan Sastra, Fakultas Ilmu Budaya Universitas Gadjah Mada

Posel: imamwicaksono@ugm.ac.id

Tim Pengabdian kepada Masyarakat:

Amir Ma’ruf, Syamsul Hadi, Sangidu, M. Masrukhi, Fadlil Munawar Manshur, Hindun, Uswatun Hasanah, Abdul Jawat Nur, Arief Ma’nawi, Mahmudah, Zulfa Purnamawati, Hamdan, Siti Aminah, Arief Budiman

\begin{abstract}
Dusun Klampok, Giripurwo Village, Purwosari District, Gunungkidul Regency, DIY consists of 469 families with a population of 1.543. Of the total population in Dusun Klampok, only a few of them have mastered the ability to use Arabic in their rituals, especially worship rituals that use loudspeakers and are heard by many people such as Friday sermons, recitations of prayer prayers, and azan prayers. Therefore, the community service team of the Arabic Literature, Faculty of Cultural Sciences, Gadjah Mada University took an initiative to conduct an Arabic language training program for the people of Dusun Klampok. The implementation of the program is carried out through several stages, namely (1) meetings with community leaders; (2) public lectures; and (3) intensive training. This community service activity has been successfully carried out in accordance with the goals and objectives planned at the beginning of the activity. The community of Dusun Klampok hopes that the training can be carried out continuously, so that there will be more Arabic (in liturgy) that can be improved.
\end{abstract}

Keywords: Klampok Hamlet, Arabic in liturgy, Arabic Language Training

\begin{abstract}
Abstrak
Dusun Klampok, Desa Giripurwo, Kecamatan Purwosari, Kabupaten Gunungkidul, DIY terdiri atas 469 kepala keluarga dengan jumlah penduduk sebanyak 1.543 jiwa. Dari total penduduk yang ada di Dusun Klampok, hanya sedikit dari mereka yang memiliki kemampuan berbahasa Arab dalam ritual ibadah mereka, terutama ritual ibadah yang menggunakan pengeras suara dan didengar oleh banyak orang seperti khotbah Jumat, bacaan imam salat, dan azan salat. Oleh karena itu, Tim Pengabdian kepada Masyarakat Prodi Sastra Arab, Fakultas Ilmu Budaya, Universitas Gadjah Mada berinisiatif untuk melakukan program pelatihan bahasa Arab peribadatan bagi masyarakat Dusun Klampok. Pelaksanaan program tersebut dilakukan melalui beberapa tahapan, yaitu (1) pertemuan dengan tokoh masyarakat; (2) ceramah umum; dan (3) pelatihan intensif. Kegiatan pengabdian ini telah berhasil dilaksanakan sesuai dengan sasaran, maksud, dan tujuan yang disusun pada awal kegiatan. Masyarakat Dusun Klampok
\end{abstract}


berharap pelatihan dapat terlaksana secara berkelanjutan sehingga akan ada lebih banyak lafaz bahasa Arab peribadatan yang dapat diperbaiki.

Kata kunci: Dusun Klampok, bahasa Arab peribadatan, pelatihan bahasa Arab

\section{Pendahuluan}

Pedukuhan Klampok adalah sebuah perdukuhan yang berada di dalam kawasan Desa Giripurwo, yang masuk dalam wilayah Kecamatan Purwosari, yang merupakan salah satu kecamatan dari Kabupaten Gunungkidul, Daerah Istimewa Yogyakarta. Sebagian besar wilayah ini merupakan daerah bebatuan yang memiliki relief dataran naik turun berbukit terjal yang tandus dan hanya sebagian kecil dari kawasan Klampok memiliki dataran yang rata. Di tengah gersangnya kawasan bebatuan dapat ditemui beberapa mata air yang menjadi sumber kehidupan masyarakat sekitar. Beberapa titik sumber air yang ada di tengah masyarakat dijaga dan dirawat kebersihannya oleh warga sekitar sebagai wujud syukur dan kesadaran akan pentingnya keberadaan sumber mata air tersebut. Di sekitar sumber air yang masih berfungsi biasanya ditemukan pohon besar. Pohon besar ini juga dilestarikan keberadaannya oleh masyarakat dan tidak ditebang. Apabila terlihat beberapa dahan yang berpotensi akan jatuh, masyarakat cukup memangkas beberapa bagian yang berpotensi menimbulkan bahaya serta untuk menghindari batang daun yang terlalu rimbun, yang dikhawatirkan akan menumbangkan pohon, mengingat usia pohon yang sudah cukup tua.

Sistem kemasyarakatan yang ada di Dukuh Klampok dipimpin oleh seorang kepala dukuh yang menjadi titik koordinasi dari pemerintah ke masyarakat atau sebagai penyambung lidah masyarakat dalam menyampaikan aspirasi ke pemerintah desa. Apabila dilihat dari segi agama, mayoritas masyarakat Klampok beragama Islam, yakni dengan persentase 98 persen. Beberapa warga dengan usia lanjut beragama non-Islam, namun anak dan keturunannya semua beragama Islam. Masyarakat Klampok sebagian besar mencari kehidupan dengan berladang atau berkebun, memanfaatkan lahan yang luas hampir di setiap depan rumah penduduk. Pekerjaan lainnya adalah seperti peternak. Warga yang berprofesi sebagai pedagang atau pegawai sangat jarang ditemui. Masyarakat Klampok tidak menyimpan hewan ternak mereka di tengah lingkungan permukiman yang ditinggali. Mereka membuat kandang untuk hewan ternak mereka di kawasan hutan yang jauh dari permukiman warga. Tim $\mathrm{PkM}$ tidak menemukan kandang yang berisi hewan ternak di tengah permukiman warga, kecuali ayam.

Melihat masyarakat Klampok dari segi usia, mereka dapat digolongkan ke dalam beberapa kelompok. Kelompok pertama yaitu warga berusia anak-anak yang memiliki kuantitas cukup banyak. Sebagian besar dari mereka adalah pelajar di sekolah dasar dan menengah. Mereka aktif dalam berbagai kegiatan dan memiliki hubungan dekat serta saling mengenal. Kelompok kedua yaitu golongan remaja atau awal dewasa, yakni mereka yang telah lulus sekolah menegah atas. Kelompok ini sangat sulit ditemui di Klampok. Sebagian besar dari mereka tidak tinggal di Klampok, tetapi merantau ke kota untuk mencari pekerjaan dan penghidupan yang lebih baik. Mereka tidak ingin menjadi pekerja di ladang seperti orang tua mereka yang terbatas dalam penghasilan yang diperoleh. Kelompok ini terbagi menjadi dua, yakni kelompok yang benar-benar merantau ke kota dan akan kembali apabila libur bekerja dan kelompok yang pergi 
ke kota untuk bekerja di pagi hari lalu saat malam hari mereka kembali ke Klampok sekadar untuk beristirahat. Kelompok ketiga yaitu warga usia dewasa atau orang tua yang merupakan warga berusia 35 tahun hingga usia lanjut. Sebagian besar dari mereka bekerja mengolah tanah luas di sekitar rumah mereka dan menjadikan lahan tersebut ladang yang ditanami berbagai macam tumbuhan yang dapat menghasilkan, seperti singkong dan lain sebagainya.

Di Dusun Klampok terdapat 469 keluarga dengan jumlah penduduk sebanyak 1.543 jiwa. Dari total penduduk yang ada di Dusun Klampok, hanya sedikit dari mereka yang memiliki kemampuan berbahasa Arab dalam ritual ibadah mereka, terutama ritual ibadah yang menggunakan pengeras suara dan didengar oleh banyak orang seperti khotbah Jumat, bacaan imam salat, dan azan salat. Hal yang patut diperhatikan adalah tentang pelaksanaan azan salat yang menggunakan pengeras suara sehingga terdengar ke berbagai penjuru desa. Akan sangat baik apabila azan yang merupakan panggilan untuk ibadah dikumandangkan dengan suara, irama nada, dan pengucapan huruf Arab yang baik dan benar sehingga dapat membangkitkan semangat untuk beribadah. Hal yang serupa juga seharusnya terdapat pada pelaksanaan khotbah Jumat. Idealnya, yang terkandung di dalam khotbah Jumat merupakan kewajiban untuk membacakan ayat Alquran, berselawat kepada Nabi Muhammad, serta perintah untuk melaksanakan takwa yang dapat diucapkan dengan pelafazan huruf Arab yang baik dan benar guna memberikan pemahaman yang baik kepada jemaah khotbah tersebut. Hal yang juga menjadi perhatian adalah imam salat saat memimpin salat berjemaah yang menggunakan suara keras, yaitu salat Magrib, salat Isya, dan salat Subuh.

\section{Permasalahan}

Dalam peribadatan berbentuk ritual yang dilaksanakan oleh masyarakat, ada beberapa macam yang diperbolehkan menggunakan bahasa Indonesia, seperti pengucapan doa. Masyarakat muslim yang melakukan ibadah doa diperbolehkan menggunakan bahasa Indonesia demi ketepatan dan kekhusyukan permohonan karena seseorang yang mengucapkan doa mengetahui dan memahami permohonan dalam doa yang mereka ucapkan.

Beberapa peribadatan lain dalam agama Islam seperti pengumandangan azan, pembacaan ayat Quran dalam khotbah Jumat, pelantunan surat Alfatihah saat salat, dan pelafazan semua bacaan salat lainnya adalah peribadatan menggunakan bahasa Arab, yang dalam syariat Islam pengucapannya tidak boleh diterjemahkan ke dalam bahasa Indonesia.

\section{Azan}

Seseorang yang bertugas sebagai penyeru azan hanya diperkenankan mengumandangkan azan sesuai dengan lafaz Arab. Sebagian besar masyarakat di Dusun Klampok memiliki latar belakang pendidikan yang rendah dan tidak memiliki kemampuan membaca bahasa Arab dengan baik dan benar. Sebagian dari petugas azan yang menjalankan tugasnya berusia di atas 50 tahun. Mereka dapat menguasai azan bukan karena menguasai bahasa Arab, melainkan karena mendapatkan tata cara azan hanya melalui tutur lisan. Mereka tidak menggunakan tulisan sebagai dasar pembelajaran. 


\section{Khotbah Jumat}

Hal yang sama juga terjadi pada para petugas yang mempunyai peran sebagai khatib Jumat. Dalam pembukaan khotbah Jumat wajib dibacakan ayat suci Alquran yang menggunakan bahasa Arab karena apabila sudah diterjemahkan ke dalam bahasa Indonesia tidak lagi dapat disebut dengan Alquran, tetapi sudah berubah menjadi terjemahan Alquran. Fenomena yang terjadi adalah ketidakmampuan petugas khatib untuk membaca tulisan abjad Arab dengan baik. Oleh karena itu, mereka membawakan khobah yang terdapat bahasa Arab di dalamnya dengan menggunakan teks yang semuanya berbahasa Indonesia. Proses pembacaan huruf latin yang merupakan transliterasi dari huruf Arab bukanlah solusi yang dapat menyelesaikan masalah karena para pemberi khotbah juga tidak menguasai dengan baik perihal pembacaan huruf hasil transliterasi. Hal yang sering terjadi di berbagai khotbah adalah kekeliruan atau tertukarnya pembacaan huruf-huruf antara ش

\section{Salat dan Pengimaman Salat}

Tidak terkecuali, kewajiban menggunakan bahasa Arab dalam beribadah adalah bacaan-bacaan yang terdapat dalam ibadah salat. Seluruh bacaan dalam ibadah salat menggunakan bahasa Arab. Dalam pelaksanaan salat Magrib, Isya, dan Shubuh, seseorang yang mendapat tugas sebagai imam harus memimpin salat dengan mengeraskan bacaan surat Alfatihah dan ayat Alquran yang dibaca setelahnya. Sebagian dari petugas yang bertindak sebagai imam salat masih melakukan kesalahan pada pembacaan Alfatihah dan surat-surat pendek.

Permasalahan-permasalahan yang ada pada masyarakat seperti yang telah disebutkan di atas menjadi perhatian tim Pengabdian kepada Masyarakat dari Prodi Sastra Arab, Fakultas Ilmu Budaya, Universitas Gadjah Mada karena peribadatan yang disebutkan di atas merupakan ritual ibadah yang dilakukan rutin setiap pekan, setiap hari, bahkan ada yang dilakukan setiap hari sebanyak lima kali, yaitu azan.

\section{Pelaksanaan}

Rangkaian kegiatan Pengabdian kepada Masyarakat Prodi Sastra Arab, Fakultas Ilmu Budaya, Universitas Gadjah Mada dilaksanakan mulai Kamis, 18 Oktober 2018 hingga Sabtu, 20 Oktober 2018 di Masjid Baiturrahim, Dusun Klampok, Giripurwo, Purwosari, Gunungkidul, Daerah Istimewa Yogyakarta. Rangkaian kegiatan ini melibatkan dosendosen Prodi Sastra Arab dan tim mahasiswa yang membantu kegiatan pengabdian. Kegiatan dimulai dari persiapan, pelaksanaan, hingga penyusunan laporan. Mahasiswa yang terlibat mempunyai kesempatan untuk belajar mengaplikasikan pengetahuan yang mereka miliki dengan beberapa peran yang telah dibagi, seperti pembawa acara, tutor pendamping saat pemberian materi, dan mempersiapkan modul materi pengabdian.

\section{Pertemuan dengan Tokoh Masyarakat Setempat.}

Sebelum mengadakan pelatihan kepada masyarakat, tim $\mathrm{PkM}$ melakukan pertemuan dengan tokoh masyarakat atau unsur masyarakat setempat yang dihadiri oleh Kades, Sekdes, Kesra, Kadus, Ketua Takmir, dan beberapa perwakilan masyarakat Dusun Klampok. 
Pertemuan berlangsung mulai pukul 16.00 s.d. 17.00 WIB. Dalam pertemuan tersebut banyak dibahas tentang kehidupan sosial dan keberagamaan masyarakat Dusun Klampok, seperti komposisi agama yang dianut masyarakat, kualitas kerukunan hidup antarumat beragama, komposisi tingkat pendidikan masyarakat, dan kemampuan masyarakat dalam memenuhi kebutuhan hidup sehari-hari. Pada akhir pertemuan yang berlangsung dengan nuansa kekeluargaan itu disepakati bahwa (1) hubungan antara masyarakat dan para akademisi harus terjalin dengan baik, (2) para akademisi berkomitmen untuk mengamalkan ilmu pada kehidupan bermasyarakat sebagai wujud pengabdian, (3) masyarakat Dusun Klampok siap menjadi desa binaan, (4) masyarakat, tokoh masyarakat, dan unsur akademisi siap menjadi agen perubahan menuju perbaikan, dan (5) Pengabdian kepada Masyarakat di Dusun Klampok diharapkan dapat memiliki agenda yang berkelanjutan untuk dilaksanakan pada kemudian hari.

\section{Ceramab Umum}

Kegiatan pembelajaran resmi Pengabdian kepada Masyarakat Dusun Klampok diawali dengan acara ceramah umum yang disampaikan oleh Dr. Moh. Masruhi, M.Hum. Kegiatan ini dilaksanakan di ruang utama Masjid Baiturrahiim setelah Salat Maghrib berjamaah bersama masyarakat yang antusias. Tidak hanya ruang utama masjid yang dipenuhi oleh masyarakat yang hadir, tetapi teras dan halaman masjid yang dinaungi tenda pun terisi penuh.

Narasumber menyampaikan beberapa materi utama. Materi yang pertama yaitu tentang hubungan antara bahasa Arab dan peribadatan yang dilakukan oleh masyarakat. Narasumber menjelaskan bahwa dalam peribadatan yang dilakukan sehari-hari ada beberapa bagian ibadah yang wajib menggunakan bahasa Arab tidak dengan terjemahan seperti azan, pembacaan ayat Quran saat khotbah, dan semua bacaan salat, terutama bacaan yang dilantunkan imam masjid saat memimpin salat berjamaah pada salatsalat yang menggunakan suara keras seperti Magrib, Isya, dan Subuh. Oleh karena itu, akan lebih baik apabila muslim yang menunaikan ibadah-ibadah tersebut dapat membaca atau melafazkan bahasa Arab dengan baik dan benar, terutama pada bagian ibadah yang menggunakan pengeras suara sehingga didengar oleh orang banyak. Apa yang diperdengarkan kepada orang banyak pada hakikatnya bertujuan untuk syiar dan menggugah hati orang banyak untuk melakukan ibadah dan kebaikan sehingga cara penyampaiannya akan lebih mendekati keberhasilan apabila disampaikan dengan menarik, baik, dan benar.

Materi kedua yaitu kendala yang ada pada masyarakat, yakni tidak adanya pembelajaran bahasa Arab peribadatan secara tertulis. Hal tersebut diharapkan tidak menjadi alasan untuk enggan memperbaiki diri saat ada kegiatan pelatihan. Hal ini didasari dengan ajaran dalam agama Islam yang menyatakan bahwa barangsiapa yang berlatih/belajar dengan terbata-bata atau penuh kesulitan akan mendapatkan dua balasan kebaikan dibanding mereka yang sekadar membaca biasa tanpa ada kesulitan dalam belajar yang hanya mendapatkan satu balasan kebaikan. Peserta yang memiliki usia lanjut juga diharapkan tetap semangat dalam perbaikan kualitas bacaan ibadah.

Hal ketiga yang disampaikan yaitu bahwa pelatihan dan pembelajaran yang akan dilaksanakan hanya berlangsung dalam waktu yang sangat singkat. Oleh karena itu, semua peserta diharapkan dapat terus hadir dan tidak ada yang absen saat pelaksanaan 
pelatihan. Akan sangat disayangkan apabila kehadiran tim Pengabdian kepada Masyarakat Prodi Sastra Arab tidak dimanfaatkan secara optimal oleh seluruh masyarakat yang ada.

\section{Pelatihan Intensif Sesuai Kelompok}

Masyarakat yang hadir mengikuti program pelatihan memiliki berbagai macam peran dalam kehidupan bermasyarakat. Ada yang bertugas di masjid sebagai muazin, imam, khatib, dan jemaah biasa. Berdasarkan peran yang mereka jalani dalam kehidupan bermasyarakat di lingkungan masjid, maka tim pengabdian membagi mereka ke dalam beberapa kelompok belajar: muazin, khatib dan imam, serta masyarakat umum yang terdiri atas jemaah masjid.

Kelompok pertama, yaitu kelompok muazin, adalah kelompok yang komposisinya terdiri atas petugas yang mengumandangkan azan setiap waktu salat dan beberapa pemuda yang akan dikaderkan menjadi muazin bersama petugas azan yang kebanyakan sudah senior. Program kaderisasi ini bertujuan membuat pemuda merasa mendapat kesempatan untuk berpartisipasi secara aktif, membantu generasi senior dalam menunaikan tugas azan, dan menghadirkan variasi baru suara serta irama panggilan azan yang memiliki penguasaan lafaz lebih baik dan benar. Masyarakat rutin mendengar panggilan azan dengan volume suara yang keras setiap hari sebanyak lima kali. Tim pengabdian menekankan beberapa hal dalam pelatihan azan, yaitu (1) koreksi dan pelatihan pelafazan huruf Arab, (2) latihan pernapasan agar saat mengumandangkan azan tidak terpotong di tengah atau berakhir karena napas yang habis, (3) teknik menggunakan pelantang suara saat nada tinggi ataupun rendah, dan (4) pengenalan irama dasar azan.

Kelompok kedua adalah khatib. Materi penekanan kepada kelompok imam dan khatib yaitu (1) membaca pembukaan khotbah, (2) pelatihan memilih ayat sesuai tema, (3) memilih doa di akhir khobah, dan (4) pelatihan membaca Alfatihah. Kelompok ketiga adalah kelompok yang terdiri atas masyarakat umum. Kelompok ini terdiri atas grup laki-laki dan grup wanita. Penekanan dalam pembelajaran kelompok ini adalah pada materi bacaan salat dan doa sehari-hari.

\section{Penutup}

Iklim keilmuan yang erat bersinggungan dengan kalangan dosen dan mahasiswa akan sangat baik bila dapat didekatkan kepada masyarakat umum, terutama yang berdomisili di perkampungan atau pedesaan. Masyarakat pedesaan selama ini banyak bersinggungan dengan dunia kerja yang menggunakan kekuatan fisik. Mereka setiap hari melawan lelah demi mencari nafkah untuk menyambung hidup. Penghasilan atau pendapatan merupakan pikiran utama mereka. Masalah kualitas pengucapan bahasa Arab dalam ibadah bukanlah perhatian utama mereka. Banyak kekeliruan ditemui di masyarakat, yang berlangsung turun-temurun dari satu generasi ke generasi selanjutnya.

Tim Pengabdian kepada Masyarakat Prodi Sastra Arab FIB UGM telah mendapatkan informasi terkait kebutuhan masyarakat akan pengetahuan bahasa Arab dan melakukan langkah-langkah konkret berupa pengabdian kepada warga Dusun Klampok, Desa Giri Purwo, Kecamatan Purwosari, Kabupaten Gunungkidul, serta mendapatkan beberapa hal sebagai berikut.

1. Masyarakat dari pagi hingga petang lelah bekerja di ladang atau melakukan 
pekerjaan yang menggunakan fisik. Waktu dan tenaga mereka terkuras banyak sehingga tidak sempat memperbaiki lafaz ibadah yang mengandung bahasa Arab.

2. Pengajaran bahasa Arab peribadatan hanyalah secara lisan turun-temurun dari satu generasi ke generasi setelahnya sehingga kekeliruan akan mudah terjadi tanpa ada teks yang menjadi rujukan.

3. Masyarakat mampu menerima materi pelajaran dengan senang dan mudah apabila materi disampaikan dengan sedikit sentuhan budaya Jawa, seperti peribahasa Jawa atau bahasa Jawa.

4. Masyarakat berharap pelatihan dapat terlaksana secara berkelanjutan sehingga akan ada perbaikan terhadap banyak lafaz bahasa Arab peribadatan. 